KAIROS ELT JOURNAL, Vol. 2, No. 2, August 2018

Copyright $\odot 2018$, ISSN: 2580-4278

\title{
IMPROVING STUDENTS' SPEAKING SKILLS BY USING PICTURE-CUED MEDIA TO THE EIGHTH GRADE STUDENTS OF SMP SANTO YOSEPH MEDAN
}

\author{
Julia Marito Simamora, Novalina Sembiring, Jontra J. Pangaribuan \\ Catholic University of Saint Thomas
}

\begin{abstract}
Speaking is considered as an important skill to be accomplished by students. As a language is used as a tool of communication, the ability of speaking or communicating with others takes an important role. People should know how to express thoughts, opinions, feelings, and ideas through the language. Teachers can also use media to enable the students to present ideas to individual peers, peers group, and entire classes. For example, students learn to speak on a subject of their own choice or on the teacher's topic through picture-cued media.

This study is a Classroom Action Research which focuses on improving students' speaking skills by using picture-cued media. The teaching process was carried out in two cycles. The data consist of observation sheet and test. The data from the observation that have been taken from every cycle are analyzed descriptively, while the data from test are analyzed quantitatively. The result of this study shows that using picture-cued media can improve students' speaking skill. This is proven by students' test score that improved in each test. In the pre-test, the students' average score is 53.8. While in the formative test cycle I, the students' average score is 61.58 , and in the post-test cycle II, the students' average score is 78.8 . That means the picture-cued media can improve the students' speaking skill significantly.

In this research, it is recommended that if the students are not confident in their speaking skills, the students can be given chances to prepare. Teachers are recommended to provide the interesting picture-cued media, control the students' activities in the classroom, give clear instructions and give chances to practice their English as frequently as possible by using picture-cued media.
\end{abstract}

Keywords: classroom action research, speaking, picture-cued media

\section{INTRODUCTION}

In the language teaching, especially teaching English as a foreign language, teachers mostly spend much of the time on appropriate teaching activities. This is the way teachers help their students in learning English. There are four skills that should be mastered namely listening, speaking, reading and writing. Speaking is considered as an important skill to be accomplished by students. As a language is used as a tool of communication, the ability of speaking or communicating with others takes an important role. People should know how to express thoughts, opinions, feelings, and ideas through the language. Teachers can also use media to enable the students to present ideas to individual peers, peers group, and entire classes. For example, students learn to speak on a subject of their own choice or on the teacher's topic through picture-cued media.

Classroom speaking activity is an activity that leads students to speak up. Speaking activities, in which students try to use any language they know, provide feedback for both teacher and students. In this case, students' speaking skills need to be improved. In the real life situation, students need to express their feeling by using a language. Therefore, speaking activities should help them to act as if they are in a real-life situation.

According to Hughes (2002: 90), the teaching of speaking depends on the existence of a classroom culture of speaking and that classroom needs to become "talking classroom". This 
KAIROS ELT JOURNAL, Vol. 2, No. 2, August 2018

Copyright $\odot 2018$, ISSN: 2580-4278

will provide students with confidence when speaking activity is a regular feature of lesson. Immediately, students' speaking skills will be improved.

Using media in teaching will help students enjoy the speaking activities, especially when the teacher asks them to tell their personal experience. Both teachers and students can provide suggestions for students' speeches. Giving feedback can improve students' speaking skills. Media are the best tool to help students in exploring their ideas and imaginations. Teachers are responsible to educate the students, from little or no knowledge to sufficient English speaking environment (Arianti \& Nadeak, 2019). Teachers should encourage an effective communication in daily life, by practicing effective expression, increasing vocabulary, giving sample opportunities that use language to describe, compare and relate experiences, thought and feeling. This demands teachers to enrich themselves with appropriate ways of teaching style. The teaching learning process should not happen only among teacher and students but also among students and students.

Based on the observation and interviews conducted by the researcher to the grade VIII students of SANTO YOSEPH MEDAN, however, some problems were still found in the students' abilities in English, especially in speaking. The students' speaking skills were relatively low. They had difficulties in expressing ideas and opinions orally as they were afraid of making mistakes and not confident to speak English. They still had difficulties in pronouncing certain English words. To be able to speak, instead of pronunciation, the richness vocabulary was also important. However, most students lacked vocabulary mastery and only few students in the classroom consulted a dictionary. Their competencies in grammar were also poor. Therefore, they preferred to be silent and not fully participate in the classroom activities. In addition, the classroom activities were less motivating the students in learning. The class was monotonous and less fun learning activities. Based on the conditions above, it could be concluded that the students' speaking skills were low.

In regard with the problems above, the research and the collaborator agreed to work collaboratively to overcome the problems and to increase the speaking skills' of grade VIII students of SMP SANTO YOSEPH MEDAN through picture-cued media. Picture-cued media were believed to be able to stimulate and guide the students to speak. Picture-cued media serve for illustration, develop students' imaginations, accommodate their interest, stimulate them to express their ideas and also make the learning process more interesting and entertaining.

In the classroom, a teacher must create a situation that can encourage a real communication. Picture-cued media is one of the media that can be applied in creating such situation, because picture-cued is one of potential activities that give students sense of freedom to express themselves by describing and telling everything regarding the picture to other friends.

Picture-cued media is a painting or drawing, that shows a scene, a person or thing. This media can help students communicate meaningful ideas to each other. In speaking practice students can correct one another and themselves. Furthermore, picture-cued gives more opportunities to students to take turns in speaking class. Speaking skill is essential for learning since teachers enable students to acquire insights and information, and achieve success in communication with others. Teachers can show students why good speaking is useful and even crucial in some situations. Students' speaking skill may be enhanced and tested by using picture-cued media about the object that they have chosen.

The researcher assumed that picture-cued is a combination of language and fun. Students could express their ideas freely because they did activities with their friends. Picturecued media has some strengths in improving students' speaking performance. Firstly, it created positive effect on the atmosphere of the classroom and the behaviors of the students that can make students more active and motivated to take part in classroom speaking activity. Secondly, students was able to speak freely by using picture-cued media.

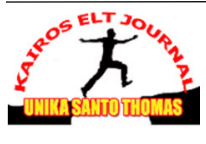


KAIROS ELT JOURNAL, Vol. 2, No. 2, August 2018

Copyright $\odot 2018$, ISSN: 2580-4278

The writer chose this media because some research findings have shown the good result of teaching speaking by using Picture-cued media. The first research which had been done by Berliana (2012) with the title "Improving Students' Speaking Skill by Using Picture-Cued in VIII A Class of SMP BPOKRI II Yogyakarta" showed a good result. She stated that students' speaking skill improved after picture-cued was applied. The second research had been done by Gallis (2014) with the title "Improving the Speaking Skill of Grade VIII Students of SMP Negeri 2 Godean Through Pictures". She stated that the mean score of post-test is higher than the mean of pre-test in cycle I. The research finding showed that students' speaking skill progressed significantly after pictures were applied.

\section{REVIEW OF LITERATURE Speaking Skills}

Speaking is different from writing in some aspects. Speaking is transitory and must be processed in real time, while written language is permanent and can be read and reread. Next, within a few moment speakers have to plan, formulate, and deliver their utterances, while writers spend more time to plan, review and revise their words. To be able to communicate, both speakers and listeners need to be present during the activity.

Unlike writing, speakers do not need to carry much information to enhance a message as they employ various devices such as stress, intonation, pitch, volume, pausing, etc. From the complexity of clauses, speakers tend to have shorter clauses than the writers do. The next aspect is related to the use of formality. Because of the social and cultural uses to which writing is ordinarily put, writing tends to be more formal than speaking. While in speaking, the formality usually depends on the occasions and the audiences the speakers communicate with. The last is that vocabulary used in written texts tends to contain a wider variety of words than oral texts.

Louma (2004:12) underlines that a major difference between speech and writing is that speakers do not usually speak in sentences. Rather, speech can be considered to consist of idea units, which are short phrases and clauses connected with and, or but, or that, or not joined by conjunctions at all but simply spoken next to each other, with possibly a short pause between them. Brown (2000:270-271) asserts other characteristics of speaking which can make oral performance easy as well as difficult in some cases. They are clustering, redundancy, reduced forms, performances variables, colloquial language, rate of delivery, stress, rhythm, and intonation, and interaction.

The first characteristic is clustering, which means that fluent speech is phrasal, not word by word. Speakers can do such clustering or joining some sounds to organize their output both cognitively and physically. The second is that the speakers have an opportunity to make meaning clearer through the redundancy of language. The next is the use of reduced forms, meaning that instead of producing a bookish speech, the speakers tend to develop contractions, elisions, reduced vowels, etc. One of the advantages of spoken language is that the process of thinking as the speakers speak allows them to manifest a certain number of performances hesitations, pauses, backtracking, and corrections. Learners can actually be taught to use such performance variables such as how to pause and hesitate. Colloquial language is one of the characteristics of spoken language that the learners should be familiar with the words, idioms, and phrases and get practice in producing these forms. Another salient characteristic of fluency is rate of delivery. Teachers should help learners to achieve an acceptable speed along with other attributes of fluency. Stress, rhythm, and intonation are the most important characteristic of English pronunciation as the stress-timed rhythm of spoken English and its intonation patterns convey important messages. The last is interaction. Learning to produce waves of language without interlocutors will rob speaking skill component, like the creativity of conversational negotiations.

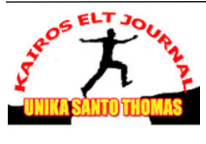


KAIROS ELT JOURNAL, Vol. 2, No. 2, August 2018

Copyright $\odot 2018$, ISSN: 2580-4278

As the speaker encounter some difficulties during the performances, especially when the speakers do not know a word or are not able to memorize it, they can employ some strategies proposed by Harmer (2007:227). The strategies can be in the forms of improvising, discarding, foreign sing, and paraphrasing. Improvising means that the speakers try to use any word or phrase which is expected to be about right. While in discarding, they can simply leave the words which are difficult to say. The next strategy is foreign sing, choosing a word in the language the speakers know (such as their first language) to be foreign with the hope that the meaning will be equivalent to the foreign language word they wish to express. The last is paraphrasing in which the speakers use such lexical substitution about the word they do not know through giving explanations or examples to paraphrases it.

Brown (2000:250-251) divides spoken language into two types, monologues and dialogues. The firs type is monologues, in which a speaker uses spoken language for any length of time as speeches, lectures, readings, news broadcasts, etc. Planned monologues usually manifest little redundancy and are therefore relatively difficult to comprehend. While unplanned monologues exhibit more redundancy, which makes for easy in comprehensions, but the presence of more performance variables and other hesitations can either help or hinder comprehension.

As opposed to monologues, dialogues involve two or more speakers. The exchanges can be interpersonal, which promotes social relationship, and transactional of which the aim is to exchange information.

To sum up, speaking is a productive language skill in which the activity includes two or more people having interaction in order to deliver or get message through the use of verbal and non-verbal languages. Furthermore, a speaker needs to use the most appropriate words and the correct grammar to convey meaning accurately and precisely, and needs to organize the discourse so that the listeners will understand. With regards to its natures, speaking is considered difficult. The understanding of the characteristics of speaking above may lead the speaker to succed their performances. Thus, speaking should be well learnt by the learners from the very basic.

\section{Types of Speaking Performance}

There are some categories of speaking performance that should be understood by teachers as those focus on different speaking skills. Brown (2001:271-274) lists six categories that students are expected to carry out in the classroom namely imitative, intensive, responsive, transactional, interpersonal, and extensive.

In imitative activity, the students simply parrot back. The focus is on some particular element of language forms such as practicing an intonation contour or trying to pinpoint a certain sound.

One step beyond imitative, in intensive performance the students practice some phonological or grammatical aspect of language. Intensive speaking can be self-initiated or it can even form part of some pair work activity.

While in responsive performance, the student's performances in the classroom are in the forms of short replies to teacher or student-initiated questions or comments. This type of speaking performance includes direct interactions which are limited to respond a very short conversation.

The next types are transactional and interpersonal. They are quite similar as in the performance the students deal with a dialogue. The function, however, are different as the transactional dialogues is to exchange specific information, while in the interpersonal one, the students are maintained to deal with social relationships. 
KAIROS ELT JOURNAL, Vol. 2, No. 2, August 2018

Copyright $\odot 2018$, ISSN: 2580-4278

The last speaking performance is extensive or monologue. The students are called on to give extended monologues. The monologues can be in the forms of short speech, oral presentation, or telling story which can be planned or impromptu.

\section{Classroom Speaking Activity}

Harmer (2007:348-352) proposes several classroom speaking activities namely acting from a script, communication games, discussion, prepared talks, questionnaires, simulation, and role-play.

The first is acting from a script. The activity can be in the forms of acting out scenes from plays or their course book and acting out dialogues they have written themselves.

The second is communication games. There are two particular categories of communication games, information-gap activities, students with their partners solve a puzzle, draw a picture, put things in the right order or find similarities and differences between pictures. While, television and radio games provide fluency activities for the students.

The third is discussion. It can be done through buzz groups, instant comment, formal debates, unplanned discussion, and reaching consensus.

The fourth is prepared talks, as the students cannot make an oral presentation or talk spontaneously because they need to prepare. In the preparation time, the teacher may help them by giving feedback, for example, and then give opportunities to them to rehearse their presentation.

The next is questionnaires. This is an interactive activity, as both questioner and respondent, through this activity, have something to say each other related to what information should be gained based on the list of questions prepared.

The last is simulation and role-play. From simulation and role-play, students get great benefit as they simulate a real life encounter as if they were doing in the real world.

In regard with the activities which are able to promote the students' speaking skills, teachers may apply those activities in the classroom.

\section{Teaching Speaking}

According to Brown (2001:7) teaching is guiding and facilitating learning, enabling learner to learn, setting the conditions for learning. It means that teaching speaking is guiding and facilitating learners to speak, enabling learner to learn speaking and setting the conditions for learning speaking.

The success of productive-skill (writing and speaking skill) tasks relies on the way teachers organize the activities and how they respond to the students' work. Harmer (2007:275) suggests a basic methodological model for teaching productive skills which is embedded in the teaching and learning process done in this research study. The steps are lead-in, set the task, monitor the process, and task feedback.

The teaching is started by leading in the students to the topic. In this step, they teacher may ask them some questions related to the topic to activate their background knowledge.

The next step is setting the task. After engaging the students with the topic, the teacher explains what the students are going to do. The teacher needs to demonstrate the activity as well as to provide all the information needed to run the activity.

After the activity is started, the teacher monitors the process. He/she may go around the class, listen to the students working, and also help them when they find difficulties.

Once the activity has finished, the teacher gives feedback to the students. In giving feedback, the responses are not focused on the language used by the students, but also the content of the task.

\section{The Roles of the Teacher in Speaking Class}


KAIROS ELT JOURNAL, Vol. 2, No. 2, August 2018

Copyright $\odot 2018$, ISSN: 2580-4278

The role of teacher during the teaching and learning process may change from one activity to another activity. Teacher plays many roles in the classroom during the teaching and learning process. Harmer (2007:347-349) states that teacher's role include assessor, prompter, participant, and feedback provider.

1) Assessor

Teacher as an assessor means the teacher acts as an assessor. The assessor has some duties such as offering the feedback, correcting and grading the students in various ways. The teacher's role as an assessor will help the students to comprehend the indication whether they are getting their English better or not.

2) Prompter

Teacher as a prompter means the teacher acts as a prompter. In this situation, a prompter has some duties such as giving helps and supporting the students by offering discrete suggestions. For example, some students usually find many difficulties during the speaking activity. In this case, the teacher should change the role into a prompter in order to encourage the students to learn. On the other hand, the teacher should not drill the students to have an excessive practice since the teacher should not disrupt the activity during the learning process.

3) Participant

Teacher as a participant means the teacher acts as participant during the speaking activity. The teacher sometimes find a difficult situation when he or she is checking the students' progress in speaking. In order to overcome the situation, the teacher has to change the role into a participant. In this case, the teacher will take part of the speaking activity as a participant, not as a teacher. By changing the role as a participant, the teacher will be easier to monitor the students' progress during the speaking activity. However, there is one condition that the teacher should note that he or she has to provide the students enough opportunity to talk than the teacher.

4) Feedback provider

Teacher as a feedback provider means the teacher acts as a person who will give a feedback to their work. In speaking activity, the teacher's role as a feedback provider is very important because the students need to get a feedback immediately during the speaking activity. However, the teacher should consider the right occasion to give them a feedback.

\section{Media}

Learning is a process to acquire knowledge. It needs hard work and sometimes will make students frustrated and get bored, so that they lose their attention to a lesson. In this case, the use of media in teaching learning process is needed to attract students' attention and to make teaching learning process more interesting and effective. Media is a tool to give learning information message. In teaching learning process, media is very important because it helps teacher to explain the lesson to the students who do not understand.

Media are the means for transferring or delivering messages. Media are flexible because they can be used for all level of students and in all subjects. By using media in teaching, student's improvement can be seen clearly. The use of media leads students to learn by doing. In other word, we can say that in learning by doing process, student improve themselves from know nothing to know something, from knowing something to understand the concept. When students use media in learning, then they will have the experience of learning and directly involve in the learning process. It makes what they have acquired will be saved in their long term memory.

\section{The Kinds of Media}

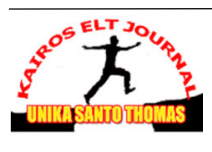


KAIROS ELT JOURNAL, Vol. 2, No. 2, August 2018

Copyright $\odot 2018$, ISSN: 2580-4278

Basically, media could be defined as the carrier of the massage of the teacher to students. On learning activity media can help the teacher in conveying the teaching material so that, the students will clearly understand about the topic.

There are 3 kinds of media:

1. Visual media is media that can be seen and touched by students, example: picture, photo, real object, map, flashcard, etc.

2. Audio media is media that contains recorded text to listen, example: radio, and cassette recorder.

3. Audio visual media is media that can be seen, touched, and listened, example: TV, film, etc.

In this research, the researcher will use visual media because picture can be seen and touched by students.

\section{Picture-Cued Media}

Picture-cued is a media that is used to elicit oral language performance at both intensive and extensive levels. The pictures may be very simple designed to elicit a word or a phrase. Picture-cued media is fun and useful for students when speaking in front of class. Then, picturecued gives the gap between speaking in front of the class by memorizing with no extra help.

Harmer (1998:87) defines speaking activity as an activity or a task which demands the students to have speaking ability to communicate, express thoughts, ideas, feeling orally, he also states that in speaking activity the students are using any all the language at their command to perform some kind of oral task and that a good speaking activity can and should be highly motivating. Therefore, the teacher should implement the media which provides an activity or task which is aimed to provoke the learners to speak or to communicate actively.

Littlewood (1981) suggests the use of picture-cued in practicing dialogs in speaking activities. He calls these activities as cued dialogue. According to Littlewood (1981:51), picture-cued gives the interaction some of the uncertainty and spontaneity involved in real communication because each learner must listen to his partner before formulating a definite response. On the other hand, the cues enable them to predict a large proportion of what the other will say, and of course, to prepare the general gist of their own response.

\section{The Benefits of Using Picture-Cued Media}

Pictures are helpful to support the teaching and learning process. There are several advantages of using pictures in teaching English. According to Harmer (2001:134) pictures really help to reduce preparation time. Sets of pictures can be re-used, especially it can be laminated, and can be used at any level classes for kids, teenagers, exam classes and adult following general or business courses. When it comes to using picture stories in class, the key point is not to limit teacher to typical class activities and speaking exercises. Students need as much spoken English practice as they can get. So, picture is a valuable resource as it provides a shared experience in the classroom, a need for common language forms to use in the classroom, a variety of task, and focus of interest for students.

\section{The Procedures of Using Picture-Cued Media}

The procedures of using picture-cued media can be described as follows:

1) Instructing the students to sit in groups in which each group consists of one higher achiever and two lower achiever.

2) Giving a chance to each student to choose a topic that is interesting for him or her to get pictures.

3) Assigning each student to examine the pictures by doing transforming and outlining activities.

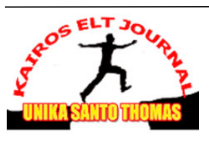


KAIROS ELT JOURNAL, Vol. 2, No. 2, August 2018

Copyright $\odot 2018$, ISSN: 2580-4278

4) Assigning each student to give monologue.

5) Providing the feedbacks toward the student's performance.

By applying picture-cued technique, the students will get opportunities to share their ideas in a group and make themselves be confident to speak through the picture-cued, so the student's speaking skill can improve as well as possible.

\section{RESEARCH METHOD}

Based on the research background presented in chapter I, the researcher decided to use action research. Burns (2010) states that action research is a self-reflective, systematic and critical approach to enquiry by participants who are at the same time members of the research community. The aim is to identify problematic situations or issues considered by the participants to be worthy of investigation in order to bring about critically informed changes in practice. Action research is underpinned by democratic principles in that ownership of change is invested in those who conduct the research (Limbong et al., 2018).

From definition above, the central idea of Action Research is to solve the problematic situation and to bring about changes and better improvements in practice. In this research study, the researcher was participated in the research in order to solve the problems existed in the teaching and learning process of speaking and to bring improvements to the students' speaking skills to the eighth grade students of SMP SANTO YOSEPH Medan through picture-cued media.

\section{DATA ANALYSIS \\ Research Process}

The findings of the research were categorized into the findings in the pre-test, students' difficulties in speaking English and action implementation.

\section{Pre-test}

In the beginning, the researcher met students on Wednesday, October 5, 2016 in VIII B Class of SMP Santo Yoseph Medan. Before conducting the first cycle, the pre-test was given to measure how far the students' speaking skill. The very first finding in this classroom action research was most of the students could not speak English fluently. The reason to this problem was because they were not confident. They never want to speak up when the teacher asked them to speak and practice in front of class. The researcher asked students to describe their favorite person in their life spontaneously, the students found the difficulty in finding the idea to describe and speak. They needed a lot time to find idea.

Some students still could not speak English fluently. They still made some mistakes in grammar and pronunciation. After conducting speaking activity, the researcher also asked the students about their opinion in speaking English. From the data, all students stated that speaking is scary and difficult.

\section{Students' Difficulties in Speaking English}

In this research, the research tried to find an action to overcome the problem. Picturecued media was chosen to improve the students' speaking skills in VIII B Class SMP Santo Yoseph Medan.

Using field notes and speaking rubrics, the researcher assessed the students' speaking skills. From these stages, the researcher could draw problems which occurred in students' speaking skills. The problems were stated as follows:

1) Students had difficulties in creating idea to talk about. For example, students often asked the teacher how to start or how to maintain the conversation.

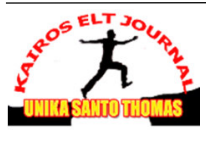


KAIROS ELT JOURNAL, Vol. 2, No. 2, August 2018

Copyright $\odot 2018$, ISSN: 2580-4278

2) Students had limited English vocabulary. For example, students often asked the teacher for the English vocabulary.

3) Students had very poor English grammar. The use of basic language structures was inaccurate. For example, "She have slim and average height body"

4) Students sometimes spoke with pauses as "ehmm......apa......"

5) Students were not confident when the teacher asked them to speak in front of class.

\section{Action Implementation}

This research was Classroom Action Research. The action would be implemented through the steps of classroom action research. This research consisted of four steps namely: planning, action, observation and reflection. Those four steps were a part of a cycle. In planning step was done to prepare everything before the teaching and learning activity. Meanwhile, the action and observation were done at the same time during the action implementation.

The result of the action would be evaluated and reflected by the researcher to figure out if the action implemented could help the students improve their speaking skills. The results were taken using the instruments of this research. The implementation of the use of picturecued media in teaching speaking was conducted in October. There were two cycles in this research. Both of the cycles were conducted in two meetings.

a. The First Cycle

The participants of this research were actually 34 students. However, in the first cycle, two students were absent because of sickness. The first cycle was conducted in two meetings on Monday, October 10, 2016 and Wednesday, October 12, 2016. The teaching and learning activities were based on syllabus and the researchers' material.

The first cycle of this research consisted of four stages namely; planning, action, observation and reflection. The action and observation were conducted at the same time. When the action was implemented, the researcher could observe what was going on during the implementation well. After that, the researcher would do reflection for the next cycle.

\section{1) Planning}

At the first time, the researcher began to plan the classroom action research by asking permission to the headmaster of SMP Santo Yoseph Medan and to the English teacher to conduct a classroom action research. After having permission, the researcher prepared the lesson plan, the model of picture-cued media. The planning step was done after the researcher found problem faced by the students in VIII B class of SMP Santo Yoseph Medan. The main focus of this step was to prepare a good media to improve students' speaking skills by using picture-cued media.

In the first meeting of the first cycle, the researcher tried to present picture-cued media. The researcher planned to show pictures to the students. Beside, the researcher also planned to provide some questions to build the students' idea knowledge based on the pictures that would be shown. The researcher also tried to find the best method to teach speaking using picturecued media. The researcher tried to use a simple picture-cued like people appearance as the model how to describe someone spontaneously. The researcher made a plan to use two picturescued media and asked the students to work in pair describing the pictures-cued based on the picture commutatively. The researcher also planned to explain language focus and gave model of describing people description based on the picture-cued media.

The researcher also asked each student to make description orally based on the picture they got while their partner gave some question about the picture-cued they had. The researcher also planned to make the action for this stage of speaking carefully. Because, this stage was very important to know whether picture-cued media improves students' speaking skills in speaking activity. The researcher only focused on the use picture-cued media to improve students' speaking skills. The researcher tried to train students' speaking problems to be their

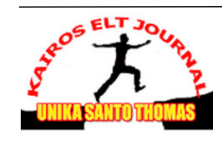


KAIROS ELT JOURNAL, Vol. 2, No. 2, August 2018

Copyright $\odot 2018$, ISSN: 2580-4278

speaking skills. During speaking activities, students got so many difficulties in speaking. Their fluency, pronunciation and vocabulary were bad. Therefore, the researcher gave the solution to repair their mistakes by using picture-cued media. Picture-cued media also could train their speaking skills in order to repair and improve their speaking skills.

\section{2) Action}

This action was conducted in meetings on Monday, October 10, 2016 and Wednesday, October 12, 2016 for ninety minutes. In this action stage, the researcher played role as the classroom teacher. In this first meeting of the first cycle, the researcher started to the action by checking students' readiness to follow the lesson and it was continued by recalling the students' speaking skills to speaking by asking some questions. The researcher explained about how to describe people appearance by giving a model of people appearance description to the students. In this stage, the researcher chose the people appearance description as a topic in speaking activity in the first cycle.

After the students had enough knowledge about people appearance description, the researcher explained how to describe people appearance orally based on a picture. She let the students participate in describing and speaking based on the picture they had. Having the picture-cued media, the researcher asked the students to works in pairs as practicing process in speaking. Each student got their own picture-cued. The students should create the description based on the picture-cued they got when their partner asked some question about their picturecued. Other partner should do otherwise. After the students work in pairs, the teacher asked some pairs to spontaneously describe people appearance description based on their picturecued.

In the second meeting of the first cycle on Wednesday, October 12, 2016, the teacher asked the students to come in front of the class independently. The teacher distributed new picture-cued media to the each students when their name was called. They should answer some questions based on picture-cued given by the teacher. Fortunately, these question could be guidance questions for students to describe their picture-cued given by the teacher. Besides, the teacher also asked other students to give comment on their performer before.

The reason why the researcher used picture-cued media was that this media could help students to build topic to talk about, to enrich their vocabulary, to increase their grammar mastery, and reduce pauses while speaking. Moreover, the students has clues to conduct speaking activities.

\section{3) Observation}

The observation was conducted at the same time with of the action implementation on Monday, October 10, 2016 and Wednesday, October 12, 2016. In the observation stage, the researcher asked for help to the real English teacher and an English teacher to observe what was going on during the action implementation.

Based on the observation during the first cycle, students were very active in making description orally. However, when the teacher asked one of the students to raise their hand and become a volunteer, nobody wanted to do it. Therefore, the teacher asked one of student to make description orally. On the first meeting of the first cycle, the teacher gave a picture about Justin Bieber who was a famous singer. The teacher asked two students to answer the question about Justin's height and face. The first student said: "Justin tall and is has long face".

The next student said; "He have long face and Justin have tall body". From those two descriptions, it could be concluded that the students were still confused how to use the structures for describing appearance. To help the students, the teacher made correction toward those descriptions by explaining that a description should have linking verb and verb correctly based on the subject.

After the first practicing, the teacher gave the second picture-cued media and asked two different students to make description about the hair and age. The second picture-cued media

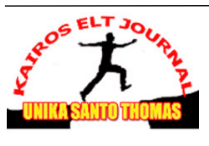


KAIROS ELT JOURNAL, Vol. 2, No. 2, August 2018

Copyright $\odot 2018$, ISSN: 2580-4278

was about a young Korean woman. The first student said: "this Korean woman is middle age and she has short brown hair". The second student said: "Korean girl is young and she has wavy brown hair". From those two students, the researcher concluded that the students had already been able to describe a picture.

In this activity, students looked very enthusiastic they could get idea to describe quickly. When the teacher asked them to describe the pictures into a good description, they could enjoy the process of describing pictures using picture-cued media given by the teacher, the teacher did not only sit down on her chair. She moved around the classroom and approached the students who wanted to ask the question. The researcher also found that the students did not know they have to use has, have, is, are, or verb.

In the second meeting of the first cycle on Wednesday, October 12, 2016, the stage of speaking was done by giving picture-cued media and asking the students to answer the questions about the picture-cued they got. Based on the observation, the students could answer the questions as guidance questions provided by the teacher correctly. The students also did not get the difficulty in looking at the picture-cued media given by the teacher. The teacher spoke clearly and loudly so that the students could understand the materials and questions. Besides, the student were very active in answering teachers' questions although sometimes they were very noisy.

\section{4) Reflection}

In this case, reflection was important in a classroom action research. The researcher reflected the action implementation in the first cycle. In the reflection stage, the researcher tried to find what went well and what did not go well. The result of the reflection stage would be used to plan for the second cycle of this classroom action research. The collaborator said that picture-cued media helped the students to understand the materials. The result was the students' speaking skills showed significant improvement.

The researcher planned to recall the students' understanding in the second cycle about the structure. The researcher reflected that this media was effective to help students' speaking energetically in English environment. In addition, the goal of using picture-cued media was visible and stimulating. The picture-cued media in which only a few could take a part while the rest have to look on, can stimulate students' skill and performance. Doing activities in pairs the students feel more confident, so the researcher would like keep this stage in the second cycle.

In the second cycle, the researcher planned to have two meetings too. The researcher planned to use the first meeting of second cycle for explaining the structures of describing someone, exercising, and practicing in pairs. Meanwhile, the second meeting of the second cycle would be independent test to compare the increasing level between the first cycle and the second cycle.

\section{b. The second cycle}

The second cycle was conducted in two meetings. The first meeting of the second cycle conducted on Monday, October 17, 2016 and the second meeting was conducted on Wednesday, October 19, 2016. In the first meeting and the second meeting of the second cycle, all students could attend the class.

The first meeting of the second cycle was to explain more about the personal description (appearance and character). The researcher also explained the structures of personal description deeply. It was to help students overcome their problem dealing with making correct structures. However the teacher who was also the researcher asked the students to practice their speaking activities using picture-cued media in pairs. Meanwhile, the second meeting of the second cycle was aimed to give opportunity to students to learn from their friends how to describe a good description using picture-cued media by giving comments their performance. Besides, the 
KAIROS ELT JOURNAL, Vol. 2, No. 2, August 2018

Copyright $\odot 2018$, ISSN: 2580-4278

students were assigned to describe personal profile based on the picture-cued media individually in front of the class.

\section{1) Planning}

Based on the problems identified in the second cycle, the researcher still used the same media because only some students were still making mistakes. The researcher only tried to find new pictures-cued which could eliminate the problems. In the first meeting of the second cycle, the researcher gave much time to practice in pairs and explain about the useful expression and vocabularies related to a personal description (appearance, job, personal profile and character) deeply. Here was the example of the picture-cued used in the research:

In this stage, the researcher planned to ask the students to work in pairs which was the same with the pairs in the first cycle so that the researcher could know the students' improvement in speaking a personal description based on the picture-cued media. Besides, by working in the same pairs, the researcher hoped that students could help each other to improve their speaking skills. The researcher assumed that the students had been able to analyze picturecued by answering the questions from their pairs and then make description based on the picture-media. The example of the such questions are like "How old is Dr.Robert? and What color are his eyes?".

On the second meeting of the second cycle, the researcher planned to ask the students to speak a personal profile description individually in front of class. The activity and the task were just the same with the first cycle. However the picture-cued media provided were different from the picture-cued in the first cycle. Picture-cued media activities offer a chance for students to talk purposefully.

\section{2) Action}

This action was conducted in the meetings on Monday, October 17, 2016 and Wednesday, October 19, 2016 for ninety minutes. In this stages, the researcher began to build the context of learning by recalling the students' understanding about describing people. Besides, the researcher also informed to the students that their previous speaking score were better than the speaking score in the preliminary study although some of them still experienced difficulty in describing people appearance and character. The researcher also gave the model of describing personal profile which was described based on picture-cued media. It made the students knew more how to analyze the picture-cued media and make some descriptions to answer the question.

To check the students' understanding about the useful expression and vocabularies related to a personal description, the researcher asked some students to describe their own picture-cued given by the teacher and let other friends to check whether the description were correct. Before the researcher gave the handouts to the students she asked about expression related to describing people. The researcher also asked the students to work in pairs and perform their conversation in front of the class. In the first meeting of the second cycle, the researcher found different atmosphere in the class. The students made a good descriptions and they performed in front of class very well. They were more relaxed and free to express their own idea and thoughts.

During speaking activities, the researcher and collaborator monitored and wrote down any significant improvement to the students who were in the researchers' main concern. After two meetings were conducted in the second cycle all students had performed their speaking skills using picture-cued media. The researcher could see the improvement in speaking elements. All the students made progress and achieved the indicators in the second cycle. Besides, the researcher sometimes asked students to repeat new words after the teacher. It was able to overcome the problem in pronunciation.

Students had improved their pronunciation too; they made few mistakes in describing activities. Moreover, they did self correction when doing a description or even their friends it after they

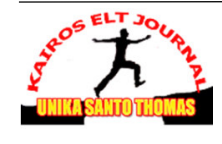


KAIROS ELT JOURNAL, Vol. 2, No. 2, August 2018

Copyright $\odot 2018$, ISSN: 2580-4278

finished. Generally, they had enriched their vocabulary by making longer conversation in pairs. Moreover, students often asked about vocabularies, the teacher answered it to the class and asked them to repeat.

\section{3) Observation}

The observation was conducted at the same time with the time of the action implementation on Monday, October 17, 2016 and Wednesday, October 19, 2016. The researcher began to build the knowledge about the lesson on the first meeting of the second cycle. Based on the observation, the students were very noisy but they listened to the teacher explanation. However, the teacher still found some students were out of control and the teacher got difficulty to manage those students. Some of the students also took notes about the material explained by the teacher.

From the observation, the researcher asked the students to describe their own picturecued media given by the researcher on by one in front of class. Then, the researcher asked whole class to check whether the description made by their friends were correct or not. Based on the observation, the students were very noisy because they discussed how to describe a picture-cued media well in pairs. The researcher thought that it was good since the students discussed something related to the task. During in this stage, the researcher moved around to help the students and also to check the students' understanding and skill in speaking a describing people task based on the picture-cued media. The researcher and collaborator also found that the students enthusiastically spoke in describing a picture-cued media. They could answer all guidance questions from their pairs based on their picture-cued media.

\section{4) Reflection}

The data identified in the observation sheet, students' score, and field notes were used as a basis to implement the next cycle or teaching learning activities. Therefore, it is the last step of the second cycle. From the implementation, the researcher recalled the student's knowledge about the structures of describing people. In this stage, the students could answer and master the materials before. The researcher reflected that this stage really went well. The researcher also gave the picture-cued media as the model was good because the students could develop their skills in speaking using picture-cued media.

In the first meeting of the second cycle, the students also could work well in pairs although they were so noisy. Besides, the researcher also move around to check the students' understanding and help them in case had difficulty in speaking using picture-cued media in pairs. The researcher reflected that giving picture-cued media could help the students to enrich students" vocabularies. Student Angel said that " kosakata saya itu banyakyang nambah Miss, ini secara langsung memaksa saya untuk menghafal banyak kosakata. Jadi saya suka belajar memakai picture-cued media”.'It was showing that students were enjoy using picture-cued media.

In the second meeting of the second cycle, the researcher employed new pictures cued as the second test media. Even though the picture-cued media had similar characteristic to the second meeting of the first cycle but after conducting it the researcher could see the significant differences. During picture-cued activities, the researcher and collaborator monitored and wrote down any significant improvement to the students. After two meetings were conducted in the first cycle and the second cycle and all students performed their performance, the researcher could see the improvement in the speaking elements. All students made progress and achieved the indicators.

1) Task completion

In the area of content all students $(100 \%)$ made progress. The teacher gave picture-cued media about personal profile and the students were supposed to answer the question from the teacher which expands it into description task. Students felt excited when doing

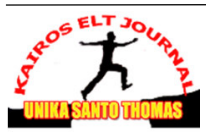


KAIROS ELT JOURNAL, Vol. 2, No. 2, August 2018

Copyright $\odot 2018$, ISSN: 2580-4278

speaking activities because their work was precious. They made longer conversation than before using picture-cued media. They could explore what they wanted to say.

2) Comprehensibility

In the area of comprehensibility of speaking, all students (100\%) made progress. Some students improved from mostly comprehensible responses to comprehensible responses and other students improved from mostly comprehensible responses to readily comprehensible responses. In this situation, the students are able to make comprehensible responses, requiring minimal interpretation on the part of pairs. The researcher found different atmosphere in class between the first cycle and the second cycle. The students made longer description and they performed on front of class very well. They were more relaxed and free to express their own ideas and thought. Students made the description based on picture-cued media given seriously even though they sometimes made jokes.

3) Fluency

Compared to the students' score of the first cycle, in the second cycle all students $(100 \%)$ improved their fluency in speaking. Even though, some students spoke continuously with few pauses and stumbling. Besides, some students spoke with frequent pauses, few thought or incomplete thought too. The rest students improved from speech halting to speech with some hesitations. In this level, students spoke with some hesitations but managed to continue and complete thoughts.

4) Pronunciation

Compared to the students' score of the first cycle, in the second cycle all students $(100 \%)$ improved their pronunciation in speaking. They made progress in improving their speaking skills. In order to overcome the problems in pronunciation, the teacher asked the students to repeat the new words after the teacher. Fortunately, the students make few mistakes in pronunciation and they had improved their pronunciation in describing activity. Sometimes, the teacher had to correct their pronunciation and asked them to correct by repeating.

5) Vocabulary

All students (100\%) improved their vocabulary in speaking. To enrich their vocabulary bank, the students used her or his own dictionary and the teacher also gave some new vocabularies list related to the materials on the handouts. The students got their own picture-cued given by the teacher and they were so enthusiastically to find vocabularies to describe the picture-cued. Even though, the students also asked the teacher appropriate words to use.

In fact, they had enriched their vocabularies by making longer description. The students often asked the teacher about vocabularies and the teacher answered it to the class and asked to repeat. Immediately, it was also used to practice their pronunciation ability. Considering their performance in front of class, the students made few mistakes on vocabularies and pronunciation.

6) Grammar

In the area of grammar, all students (100\%) made progress. Compare to the first cycle, all student made similar improvement. Students could expand their description and explore their ideas into good one. They were creative in describing their picture-cued media. Based on observation, they were very cooperative students. They helped each other when one had difficulties. The picture-cued was interesting media to practice speaking. Students interested in describing their picture-cued media in front of class, so it encouraged them to speak.

The Role of Picture-Cued Media in Improving The Students' Speaking Skills.

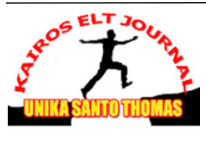


KAIROS ELT JOURNAL, Vol. 2, No. 2, August 2018

Copyright $\odot 2018$, ISSN: 2580-4278

In this stage, the researcher gave the result that would be the answer of the second objective which is to find out whether picture-cued media is useful for students' speaking skills in VIII B of SMP Santo Yoseph Medan by using students' score. The researcher also could see the result of the speaking skills based on the score that had been achieved by the students in speaking rubrics.

Before conducting the first cycle, the pre-test was given to measure how far the students' speaking skills. From the result of pre-test, it was found that only 4 students of 36 students who passed the Kriteria Ketuntasan Maksimal (passing grade) for English subject was 70. Data frequency of pre-test could be seen as follows:

Table 1. Data Frequency Distribution for Score of Pre-test

\begin{tabular}{|l|l|l|l|l|}
\hline No & Score Interval & Frequency & Percentage & Category \\
\hline 1. & $85-100$ & 1 student & $2.7 \%$ & Excellent \\
\hline 2. & $70-84$ & 3 students & $8.33 \%$ & Good \\
\hline 3. & $60-69$ & 3 students & $8.33 \%$ & Fair \\
\hline 4. & $50-59$ & 7 students & $19.44 \%$ & Poor \\
\hline 5. & $0-49$ & 22 student & $61.11 \%$ & Very bad \\
\hline
\end{tabular}

At the end of the meeting of cycle I, the researcher concluded that picture-cued as the media implemented in the first cycle was satisfying enough. From the result of formative, there were 15 students of 36 students who passed the Kriteria Ketuntasan Maksimal (passing grade) for English subject was 70. Therefore, the students could improve their speaking skills in the first cycle well. Data frequency of formative cycle I could be seen as follow:

Table 2. Data Frequency Distribution for Score of Formative Test Cycle I

\begin{tabular}{|l|l|l|l|l|}
\hline No & Score Interval & Frequency & Percentage & Category \\
\hline 1. & $85-100$ & 3 student & $8.33 \%$ & Excellent \\
\hline 2. & $70-84$ & 12 students & $33.33 \%$ & Good \\
\hline 3. & $60-69$ & 7 students & $19.44 \%$ & Fair \\
\hline 4. & $50-59$ & 11 student & $30.55 \%$ & Poor \\
\hline 5. & $0-49$ & 3 student & $8.33 \%$ & Very bad \\
\hline
\end{tabular}

Picture-cued media was also conducted in the second cycle. Based on the scores that had been achieved by the students in the speaking rubrics, the researcher concluded that their speaking skills improved. In this cycle, the students made good progress. Data frequency of formative cycle I could be seen as follow:

Table 3. Data Frequency Distribution for Score of Post-test Cycle II

\begin{tabular}{|l|l|l|l|l|}
\hline No & Score Interval & Frequency & Percentage & Category \\
\hline 1. & $85-100$ & 10 students & $27.77 \%$ & Excellent \\
\hline 2. & $70-84$ & 22 students & $61.11 \%$ & Good \\
\hline 3. & $60-69$ & 4 students & $11,11 \%$ & Fair \\
\hline 4. & $50-59$ & 0 student & $0 \%$ & Poor \\
\hline 5. & $0-49$ & 0 student & $0 \%$ & Very bad \\
\hline
\end{tabular}

To find out the students' mean score in each test, the writer applied the following formula: $\bar{X}=\frac{\sum x}{\mathrm{~N}} x 100 \%$

So, from the formula above, the results of the students' mean score was shown as follows:

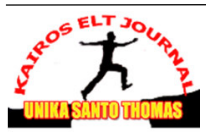


KAIROS ELT JOURNAL, Vol. 2, No. 2, August 2018

Copyright $\odot 2018$, ISSN: 2580-4278

a. In the pretest, the total score of the students was $\frac{1935}{36}=53.8$

b. In the formative cycle I, the total score of the students was $\frac{2225}{36}=61.8$

c. In the post-test cycle II, the total score of the students was $\frac{2840}{36}=78.8$

By observing the improvement of speaking skills as written in the table above, the researcher concluded that picture-cued media could improve their speaking skills. It could be seen from the score from pre-test up to post-test cycle II. In pre-test the students' mean score was 53.8, while the students' mean score in formative cycle I was 61.8 , so the increasing point was 8 points, and in post-test cycle II, the mean of the students' score was 78.8. So, the increasing point from pre-test to cycle II was 17 points.

Next, after calculating the mean of the students' score, the writer calculated it in the form of percentage to know the total of the students who passed the KKM. The writer used the following formula:

$\mathrm{P} \quad=\frac{\mathrm{R}}{\mathrm{T}} \times 100 \%$

The total number of students who passed the KKM could be seen as follow:

a. In the pre-test, the total number of students who passed the KKM was $\frac{4}{36} \times 100 \%=11.11 \%$

b. In the formative cycle I, the total number of students who passed the KKM was $\frac{15}{36} \times 100 \%=$ $41.66 \%$

c. In the post- test cycle II, the total number of students who passed the KKM was $\frac{32}{36} \times 100 \%=$ $88.88 \%$

So, from the percentage above, it could be concluded that the percentage of students who passed the KKM was increased from pre-test up to cycle II. In pre-test, the total of the students who passed the KKM was 4 students, it was $11.11 \%$. In formative cycle I, the total of the students who passed the KKM was 15 students, it was $41.66 \%$, so the difference was 30.55 $\%$, and in the pos-test cycle II, the total number of students who passed the KKM wasn 88.88 $\%$. It meant the increase of point from pre-test to cycle II was $77.77 \%$. below:

In detail, the mean of the students' score and the percentage could be seen in the table

Table 4. The Mean Score of All Test

\begin{tabular}{|l|l|l|}
\hline Kinds of Test & The Average & The Percentage \\
\hline Pre-test & 53.8 & $11.11 \%$ \\
\hline Formative Cycle I & 61.8 & $41.66 \%$ \\
\hline Post-test Cycle II & 78.8 & $88.88 \%$ \\
\hline
\end{tabular}

\section{CONCLUSIONS}

The research was proposed to find out the most appropriate media to improve students' speaking skills of the eighth grade of SMP Santo Yoseph Medan. There were two problems in this research, "what are students' difficulties in speaking skills and how does picture-cued media improve students' speaking skills".

In the first cycle, the students mostly improved only in the task completion and comprehensibility. They still needed to improve their fluency, pronunciation, vocabulary and grammar. It can be seen from the result that students made progress in overall speaking skills. In the second cycle, the researcher still implemented the picture-cued media. The students were free to express their ideas so they made longer description. They could improve all elements of their speaking skills in the second cycle.

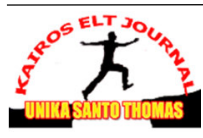


KAIROS ELT JOURNAL, Vol. 2, No. 2, August 2018

Copyright $\odot 2018$, ISSN: 2580-4278

The researcher concluded that picture-cued media could improve the students' speaking skills. There was significant improvement after the implementation of picture-cued media to teach speaking in class. Students made improvement in speaking elements: task completion, comprehensibility, fluency, pronunciation, vocabulary, and grammar. They achieved indicators in speaking skills proposed by the researcher. The researcher only focused on how the students became more confidence and could make longer descriptions. When the students could pass these targets, the researcher considered that the students could make a progress.

\section{BIBLIOGRAPHY}

Berliana, Elista. 2012. Improving Students' Speaking Skill by Using Picture-cued in VIII A Class of SMP BPOKRI II Yogyakarta. A Thesis, Unpublished. Sanata Dharma University.

Brown, H.D. 2000.Principles of Language Learning and Teaching. $4^{\text {th }}$ ed. White Plains, NY: Pearson Education.

. 2001.Teaching by Principles: An Interactive Approach to Language Pedagogy(

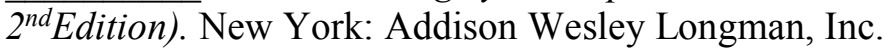

Burns, Anne. 1999. Collaborative Action Research for English Language Teacher. Cambridge University Press.

. 2010.Doing Action Research in English Language Teaching: A Guide for Practitioners. New York: Rutledge.

Gallis, N.N. 2014. Improving the Speaking Skill of Grade VIII Students of SMP

Negeri 2 Godean Through Pictures. A Thesis, Unpublished. Yogyakarta State University.

Harmer, J. 1998.How to Teach English.Essex: Longman Group Ltd. . 2007. The Practice of Language Teaching (4th Edition). London: Longman Group Ltd.

Hughes, R. 2002. Teaching and Researching Speaking. London: Pearson Education.

Louma, S.2004. Assessing Speaking, the Cambridge Language Assessment Series. Cambridge: Cambridge University Press.

Limbong, T., Simarmata, J., Sriadhi, S., S Tambunan, A. R., Keristiana Sinaga, E., Simbolon, N., P Simarmata, H. M., S Siahaan, A. L., Ruth Septarini, I., Kelana Jaya, I., Arafat Lubis, M., Khairi Siregar, I., Kristian Siburian, H., Purnomo, A., Anam, F., Azzumarito Pulungan, D., Siagian, P., Silitonga, P. D., Damanik, R., \& Pakpahan, S. (2018). The Implementation of Multi-Objective Optimization on the Basis of Ratio Analysis Method to Select the Lecturer Assistant Working at Computer Laboratorium. In International Journal of Engineering \& Technology (Vol. 7, Issue 2).

Littlewood, W. 1981.Communicative Language Teaching. Cambridge: Cambridge University Press.

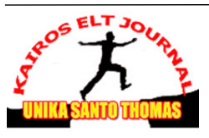

